\title{
A century of confusion in researching Alzheimer's disease
}

\author{
Mario D. Garrett*1,2, Ramón Valle ${ }^{1}$ \\ ${ }^{1}$ School of Social Work, San Diego State University, California, USA \\ ${ }^{2}$ Department of Psychology, Boğaziçi University, Istanbul, Turkey
}

Received: February 19, 2016

Accepted: April 5, 2016

Online Published: April 14, 2016

DOI: $10.5430 /$ ijh.v2n2p13

URL: http://dx.doi.org/10.5430/ijh.v2n2p13

\begin{abstract}
More than a century ago Alois Alzheimer published a case study that later evolved into the Amyloid Cascade hypothesis—which assumes that increasing proliferation of plaques and tangles in the brain cause dementia. However, studies involving the removal of plaques - amyloid- $\beta$ - in patients' brains resulted in worse cognitive performance, suggesting that plaques cannot solely be the disease. The search then focused on tau misfolded protein. But the evidence is uncertain. This paper suggests a critical history approach to understanding this confusion in Alzheimer's disease research. Confusion is related to variability in expression of the disease, inaccuracy of clinical diagnostic tools, the relationship to other diseases, and the increasing neurological variance among older adults. The final verdict is that there is an unclear relationship between the biology and the expression of the disease. Alzheimer's disease may in fact be the expression of another, yet unknown, disease. An often overlooked component in Alzheimer's disease is white matter in the brain. Although found to be negatively related to dementia and positively related to learning, white matter remains unexamined in most current research. Historical evidence suggests that this was not the case a century ago. This paper is grounded in historical observations that Alois Alzheimer and his contemporaries identified these criticisms a hundred years ago. By ignoring these criticisms today, we have ended in a research cul de sac. This paper argues for greater specificity of the definition of Alzheimer's disease and a broadening of the research focus to include the possible role of epigenetic changes, variance within older ages and brain plasticity. Only by broadening the scope of research and addressing this confusion directly can we move out of this research cul de sac and move closer to a cure.
\end{abstract}

Key Words: Alzheimer's disease, Plasticity, Neurogenesis, White matter

\section{INTRODUCTION}

This paper is a critical history of Alzheimer's diseaseexamining historical observations in order to understand intentions of early researchers-aiming to provide a more comprehensive understanding of the disease. The paper focuses on political factors that elevated Alois Alzheimer's findings to a new disease. Findings that later contributedwith input from many significant researchers ${ }^{[1]}$ _into the
Amyloid Cascade hypothesis of $1992,{ }^{[2]}$ which was later enshrined in 2011 as the guidelines for Alzheimer's disease by the U.S. National Institute on Aging. This development came at a cost of ignoring researchers' early ambivalence to these findings. Currently, research continues to ignore the role of brain plasticity and variability among older adults, in favor of biological determinism. But such reliance on biological determinism has created both clinical as well as neurobiolog-

\footnotetext{
*Correspondence: Mario D. Garrett; Email: drmariusgarrett@gmail.com; Address: School of Social Work, San Diego State University, California, 92182. USA.
}

Published by Sciedu Press 
ical confusion that we find ourselves in today. The goal of this paper is to ascertain the original meaning of Alzheimer's disease in its original historical context. By reconstructing the political climate which defined Alzheimer's disease as a definitive neurobiological disease we might understand the real meaning of why a new disease was created. Even at the inception of the disease, Alois Alzheimer himself had second thoughts: "The question therefore arises as to whether the cases of disease which I considered peculiar are sufficiently different clinically or histologically to be distinguished from senile dementia or whether they should be included under that rubric." (p. 72). ${ }^{[3]}$ Within three years, Emil KraepelinAlois Alzheimer's supervisor and director of the clinic in Munich — christened the disease by including Alzheimer's paper in the eighth edition of his book Psychiatrie and calling it Alzheimer's disease. ${ }^{[4,5]}$ In agreement with Alzheimer, Kraepelin observed that: "The clinical interpretation of this Alzheimer's disease is still confused." (p. 77). ${ }^{[6]}$ If there was confusion then, it remains with us today. By examining how the historical context made it possible for the disease to be adopted so readily, we might better understand this confusion in research and in clinical practice today.

In 1901, at the age of 51, Auguste Deter was admitted to the state asylum in Frankfurt, Germany. She was suffering from cognitive and language deficits, auditory hallucinations, delusions, paranoia and aggressive behavior. ${ }^{[7]}$ Alois Alzheimer, examined her, and when she died five years later-from septicemia and bedsores ${ }^{[8]}$ — her brain was sent to him for examination. Alzheimer's breakthrough was the observation of dense plaques and tangles in the brain of a "young" patient. This initial observation led to the Amyloid Cascade hypothesis $^{[2]}$ - positing that the accumulation of the amyloid- $\beta$ peptide in the brain is Alzheimer's disease signature pathology. ${ }^{[9]}$ As a result, most Alzheimer's disease treatments tested on humans are drugs aimed at removing amyloid- $\beta$. However, after decades of testing, the Amyloid Cascade hypothesis has received negative outcomes in clinical trials on humans. ${ }^{[10]}$ The great success of some of these drugs at removing plaques from the brains of Alzheimer's disease patients is offset by the patients' poor performance on cognitive testing. ${ }^{[11-13]}$ If the removal of the neuropathology does not reverse the disease, then Alzheimer's disease must be an expression of as yet, an unknown disease. The search has now moved from plaques to tangles-tau misfolded proteins, mirroring Oskar Fisher's century old assertion-although the outcomes from these clinical studies are still unclear and definitely not simple. ${ }^{[14]}$ This changing target and the inconsistency of outcomes remains a primary source of confusion in Alzheimer's disease research. Even existing medication-based on completely different neurobiological principles-have marginal clinical efficacy. ${ }^{[15]}$ It seems that we have reached a research and clinical cul de sac.

A hundred years ago, Alzheimer was aware of these nuances when he observed that: "There is then no tenable reason to consider these cases as caused by a specific disease process." (p. 94). ${ }^{[3]}$ And his conclusion clearly suggests that these are symptoms or "... an accompanying feature" and not a separate disease (p. 92). ${ }^{[3]}$ Despite this interpretation, and while the cause of the disease remains unknown, public research funds-almost without exception-are focused on the identification of genetic, pharmacological and neurobiological biomarkers. The failure to identify a cause has led researchers to address late onset dementia as sporadicarising or occurring randomly with no known cause. Despite many studies, because of poor methodological designs, the disease remains idiopathic, without known cause. ${ }^{[16]}$ Overall, more than four in five patients with Alzheimer's disease appear to have sporadic episodes, with onset after 65 years of age $^{[17]}$ — refuting the single reason for defining Alzheimer's disease more than a century ago, that of early-age onset. Alzheimer reports this sole distinction twice in his paper “... because senile dementia was out of the question since the patient was only 56 years of age" and then again (with a different age) "Senile dementia was never considered because of the onset at the age of $54 \ldots$. (p. 77) ${ }^{[3]}$ Seemingly there is no behavioral difference between early- and late-onset Alzheimer's disease ${ }^{[18]}$ —other than ongoing headaches, as reported by some of the familial patients in the Medallin Columbia early-onset study. ${ }^{[19]}$

\subsection{Historical and cultural roots of confusion}

In the early decades of the 1900s, three new methodologies were allowing different interpretations of the phenomena of mental illness: (1) histological staining techniques were developed to differentiate different cell types in the brain; (2) psychoanalytic interviewing techniques started looking into the subconscious mind; and (3) experimental methodologies were discovering how learning inappropriate responses have long-lasting behavioral effects. These new methodologies facilitated the separation between psychiatry, psychology and psychoanalysis. With psychiatry adopting neurobiology as its methodology.

These methodologies fell into two dominant philosophies of the early 1900s. On one hand researchers argued that genetic/biological differences in humans can determine their mental and behavioral capacities ${ }^{[20]}$ — a philosophy championed by psychiatry. In contrast, the nurture/learning philosophy - advocating that social interaction shape how we feel and behave-was endorsed by psychoanalyses and psychology. The intellectual father of modern psychiatry, Emil 
Kraepelin—who coined Alzheimer's disease in 1911, believed that there exists a genetic, biological and neuronal basis for behavior. In contrast, both Sigmund Freud and his protégée Carl Jung were proposing that upbringing and the unconscious influence behavior. While Wilhelm Wundt-the father of experimental psychology, who mentored Kraepelinbelieved that feelings, images and thoughts determine both positive and negative behaviors. Kraepelin perceived a direct threat from the nurture/learning philosophy, resulting in his pursuit to prove that cognitive problems had a genetic and biological basis, but not a psychological one. ${ }^{[21]}$ This perceived threat promoted Kraepelin's quest for biomarkers in Alzheimer's disease, a legacy that remains with us today.

An additional pressure existed for Kraepelin. The rivalry between Kraepelin's Royal Psychiatric Clinic based in $\mathrm{Mu}-$ nich, Germany - where Alois Alzheimer worked — and the German University Clinic in Prague directed by the Czech neurologist and psychiatrist Arnold Pick with his protégée Oskar Fisher. ${ }^{[5]}$ The Prague clinic had already defined Pick's disease and Pick's Bodies as forms of prefrontal dementia, and had already defined dementia praexia (premature dementia) as early as 1891, but without the histological evidence that Alois Alzheimer provided. In addition, Oskar Fisher, independently, had identified the plaques, which at the time were known as "Fisher Plaques." Fischer and others at the time also identified a type of dementia referred to as presbyophrenia. Presbyophrenia is synonymous with Alzheimer's disease-early onset dementia. In agreement with Kraepelin, Fischer was of the opinion that presbyophrenia and simple senile (late-onset) dementia were two different diseases. As a result of these advances, the Prague clinic was ahead of the game and Kreplein was aware of this advantage. Although Emil Kraepelin and Eugen Bleuler had already separated schizophrenia from senile dementia, Kraepelin needed a disease to separate senile dementia from its earlier expression that Pick had identified as dementia praexia. And this is where Alois Alzheimer's histological observations come into play.

\subsection{The resulting confusion in diagnosis}

Although Alzheimer's disease is presumed to be very specific neurobiological disease, this is not the case in clinical settings. ${ }^{[22]}$ Physicians and mental health professionals are still struggling to diagnose Alzheimer's disease correctly. ${ }^{[23]}$ The reliability of clinical diagnosis of Alzheimer's disease dementia remains low, being confused with other neurological diseases such as Creutzfeldt-Jakob disease, ${ }^{[24]}$ Lewy Body dementia, ${ }^{[25,26]}$ and Vascular dementia, which causes the highest incidence of misdiagnosis. ${ }^{[27]}$ In addition to other neurological diseases that confound diagnoses, there

Published by Sciedu Press are clinical complications such as anxiety, ${ }^{[28]}$ low education, cultural variability and the main cause of misdiagnoses, depression. ${ }^{[29,30]}$ It is rare for a brain disease in older adults to occur in isolation from depression ${ }^{[31]}$ and anxiety. ${ }^{[28]}$ The available diagnostic tools are too crude to differentiate these confounds since they measure severity rather than specific deficits.

In addition to the 2011 updated National Institute on Aging/Alzheimer's Association guidelines, other detailed criteria exist for the diagnosis of dementia. Criteria have been published by the Alzheimer's Disease Diagnostic and Treatment Centers (ADDTC), 1992; Diagnostic and Statistical Manual of Mental Disorders, 5th edition (DSM-V), 2014; International Classification of Diseases, 11th revision (ICD-11), 1994-2017; and National Institute of Neurological Disorders and Stroke-Association Internationale pour la Recherche et l'Enseignement en Neurosciences (NINDSAIREN), 1993. However, these criteria show poor consistency.

Researchers evaluating these different criteria on a sample of 167 older adult patients who were admitted to a hospital with probable dementia, found that the criteria are not specific enough to differentiate multiple types of dementia, multiple causes may exist that result in similar symptoms. ${ }^{[27]}$ They also suggest that there are other brain diseases, primarily white matter lesions, whose cause and identification remain unknown. Similar results were found ${ }^{[32]}$ reporting agreement in only 20 out of 1,879 dementia cases and 31 out of 107 patients. ${ }^{[33]}$ It is only recently that the lack of reliability in these diagnostic tools has received clinical attention. ${ }^{[34]}$

Evidence also exists that the expression of different neurological diseases is not distinct enough. In neuropathological studies, dementia with Lewy bodies and Alzheimer's disease pathology commonly coexist, ${ }^{[35]}$ and can include reversible conditions, ${ }^{[36]}$ resulting in a spectrum of clinical expression that fall within hypothetically extremes of reversible deficit, Alzheimer's disease and Dementia with Lewy bodies. ${ }^{[37]}$ As such there seems to be a continuum, rather than a difference in kind, between Alzheimer's disease and vascular dementia. ${ }^{[38,39]}$ In addition to this neurological diffusion, there exist the further complication of the diagnostic setting. Despite references to biomarkers in the literature, the clinical setting is a social exchange with social and cultural expectationsstereotypes - affecting the reporting and interpretation of behavior. Stereotypes play a significant role in diagnosis. Physicians are significantly more likely to diagnose an older adult with memory issues as having "dementia" when there is an expectation beforehand. ${ }^{[40]}$ Of particular interest to clinicians - other than the anxiety and stigma of incurring 
the dementia label, monetary costs associated with follow-up testing, or medications prescribed needlessly-is how the diagnosis, in turn, changes the behavior and memory of older adults. ${ }^{[41,42]}$ The relationship becomes a self-fulfilling prophesy wherein the patient conforms to the diagnosis, even when the diagnosis is incorrect and unjustified. ${ }^{[43]}$

The resilience of the Amyloid Cascading hypothesis, in the face of growing research discontent, can be seen when the NIA guidelines argued that the hypothesis will work if they can catch the plaques at an earlier stage of the disease. ${ }^{[4]}$ To enable this approach, the definition of Alzheimer's disease was changed to include a pre-clinical stage that is not yet expressed - creating a "prodromal" stage. ${ }^{[4]}$ While the previous (1984) guidelines only recognized two stages-early and late Alzheimer's dementia-the new guidelines propose that Alzheimer's disease progresses on a continuum with four stages. ${ }^{[4]}$ The first is an early, pre-clinical stage with no symptoms, ${ }^{[45]}$ followed by a middle stage of mild cognitive impairment, ${ }^{[46]}$ and finally two stages of mild and severe Alzheimer's disease. ${ }^{[4]}$ The authors were candid about their intentions in stating that "... These recommendations are solely intended for research purposes and do not have any clinical implications at this time" (p. 280). ${ }^{[48]}$ But the social implications are hard to dispel ${ }^{[49]}$ since dementia is the most frequently expressed fear after cancer. ${ }^{[50]}$ By broadening the definition of Alzheimer's disease to include an invisible stage is worrisome to a public already fearful of the disease and further erodes the specificity of a clinical disease. This opened the possibility of defining a clinical disease deprived of clinical evidence. ${ }^{[51]}$

\subsection{The present paradigm is sowing neurological confu- sion}

As a neurobiological proposition, the Amyloid Cascade hypothesis is difficult to validate. Alzheimer himself argued "... how difficult it is to define diseases solely with respect to their clinical features, especially in the case of those mental disorders which are caused by an organic disease process. An identical disease process will be able to cause extraordinarily different clinical features because of differences in its localization, and in the sequence and extent of cortical revolvement, which may be diffuse or localized and moreover possibly localized in many different ways." (p. 94). ${ }^{[3]}$ Contemporary neurobiological research is verifying Alzheimer's insight.

In a study of autopsied brains from 49 confirmed Alzheimer's disease patients diagnosed according to three sets of published pathological criteria, researchers found a correlation between the density of tangles in frontal and parietal lobes and cognitive deficit, whereas no correlation existed between density of amyloid plaques and cognitive deficit. ${ }^{[52,53]}$ One possible reason why older adults might have the neuropathology of Alzheimer's disease and yet not show any symptoms might be because the neuropathology is not exclusively the plaques and neurofibrillary tangles but an overall reduction of neurons in the brain. ${ }^{[54]}$ In agreement, scores on the mini-mental state correlate with grey matter density reduction. ${ }^{[55]}$ Other studies similarly show that this grey matter deficit is also accompanied by white matter deficit, where more than half of the patients diagnosed with Alzheimer's disease exhibit white matter abnormalities. ${ }^{[56]}$ The two-way communication between neurons and non-neural cells-glial cells - is essential for axonal conduction, synaptic transmission, and information processing. ${ }^{[57]}$ On the basis of these studies, it is therefore not surprising to find that abnormalities of cerebral white matter are also present in a majority of patients with Alzheimer's disease. ${ }^{[58]}$ This association was identified by Alzheimer when he wrote that: "In addition, Weigert's glial stain preparation shows another unusual finding. One can often see glial fibres, which appear coiled. This appearance does not seem to me to be without general interest: (1) ... the glia are trying to enclose and support the Corpora amylacea; (2) because they may perhaps shed some light on the physical conditions leading to the development of glial fibres (Homburger)." (p. 86). ${ }^{[3]}$

\subsection{The present paradigm is ignoring brain plasticity}

Only by ignoring this early ambivalence, did the Amyloid Cascade hypothesis become dominant. To maintain its dominance this approach continues ignoring research in brain plasticity and disease variability. But by doing so this tactic results in clinical and neurobiological confusion (see Figure 1).

The brain is an ever-evolving, changing organ. ${ }^{[59]}$ Neurological studies have shown how learning among taxi drivers changes their brain structure, ${ }^{[60]}$ especially their white matter. ${ }^{[61,62]}$ White matter is important because these glial cells have been closely tied to learning and to Alzheimer's disease from its inception (p. 3). ${ }^{[63]}$ Because white matter is more malleable than the slower growing neurons, white matter may be important indicators for learning and brain plasticity. ${ }^{[64]}$ Such neurological changes have also been observed among older adults ${ }^{[65]}$ even after suffering a stroke. ${ }^{[6]}$ Numerous studies have measured brain volumes of professional pianists, reporting a correlation between the hours a musician played and the density of their white matter. ${ }^{[67]}$ To the degree that white matter architecture differs between musicians and nonmusicians. ${ }^{[68]}$ In fact, most type of learning brings about changes in white matter, ${ }^{[69]}$ as found with playing golf, ${ }^{[70]}$ playing board games, ${ }^{[71]}$ as well as meditation. ${ }^{[72]}$ Such 
white matter changes may have lasting and positive effects on other executive functioning extending beyond the original skill. ${ }^{[73,74]}$ Although white matter can increase in response to learning new tasks, it is also prone to degradation. White matter patterns can therefore provide some explanation for the variance we see among older adults and their expression of dementia.

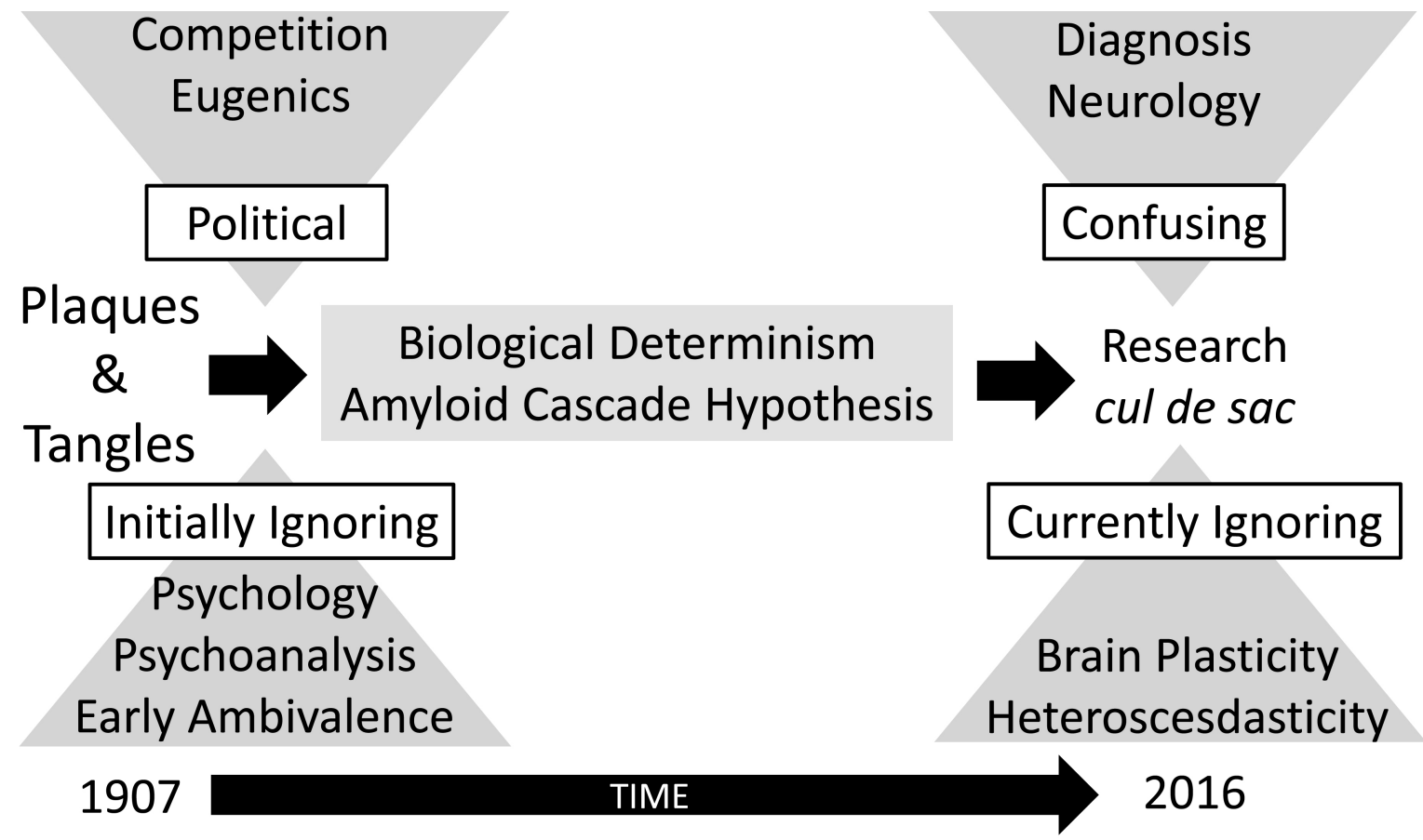

Figure 1. How biomarkers for Alzheimer's disease gained prominence through political pressures, while ignoring contradictory research, resulting in research cul de sac.

\subsection{Present Approach is Also Ignoring Heteroscedastic- ity as it Prevails Among Older Adults}

Heteroscedasticity - in this context-refers to increasing variance with older age. This diversity and variability increases as a cohort ages-unlike regular variance, which is random, the term for increasing variance along a continuum is specifically termed as heteroscedasticity. This variance was first identified in 2003 with the Nuns' Study when David Snowdon showed that dementia is mediated by education through a process identified as "... cognitive reserve-the capacity of the brain to resist the expression of symptoms in the face of existing neuropathology." (p. 453). ${ }^{[75]}$ The aging process can have both gains and losses, ${ }^{[76]}$ creating a more neurologically diverse population. Older adults have greater variance than younger age cohorts in behavior, memory, morbidity and their level of neuropathology.

Apart from around five percent of early-onset cases, most cases of dementia are senile-pertaining to old age. Alzheimer himself acknowledged this more than a hundred years ago: "Hence there appear to be a variety of intermediate forms between these presenile diseases and the typical cases of senile dementia. As similar cases of disease obviPublished by Sciedu Press ously occur in the late old age, it is therefore not exclusively a presenile disease, and there are cases of senile dementia which do not differ from these presenile cases with respect to the severity of disease process." (p. 94). ${ }^{[3]}$ Among the oldestold, when compared to younger people, Alzheimer's disease is more likely to be related to mixed disease pathologies. ${ }^{[77]}$

Heteroscedasticity might explain why multiple studies have shown that the correlation between Alzheimer's disease neuropathology and its clinical expression declines with age. ${ }^{[78]}$ In part, the loss of association reflects increasing prevalence of other, non-Alzheimer's disease cerebral pathologies in patients as they age. ${ }^{[79]}$ Interestingly, approximately half of clinically diagnosed demented oldest-old have insufficient neuropathology findings to account for their dementia, while approximately half of individuals without dementia meet the neuropathological criteria for Alzheimer's disease. ${ }^{[80,81]}$

\section{DiscuSSION}

Several major sources of confusion remain in Alzheimer's disease research. ${ }^{[30,82]}$ The primary confusion comes from the varied causes of cognitive diseases. Isolating the disease remains both a neurobiological as well as a clinical 
problem. ${ }^{[83]}$ Resulting in most dementias being misdiagnosed. ${ }^{[84-86]}$ A lack of understanding remains as to whether one disease has different expressions-e.g., Alzheimer's disease, Lewy Body Dementia, Vascular dementia-or whether different diseases can result in the same expression-e.g., Alzheimer's disease caused by either genetics or a vascular disease such as normal pressure hydrocephalus which is reversible. Therefore, it is difficult to make distinct and accurate diagnoses. This is the primary source of confusion. The concept that Alzheimer's disease is not a disease but a syndrome will provide an impetus for more research looking at the process of the disease rather than an exclusive focus on finding biomarkers.

A second source of confusion comes from the great variance among older adults' experience with the disease-namely heteroscedasticity. Even among identical twins, this drift can result in one twin experiencing Alzheimer's while the other escapes. ${ }^{[87]}$ This drift is caused by epigenetic changes that can also influence brain plasticity. Variance among individuals increases as they age and will continue to dilute the linear association between a specific disease and its expression. While researchers continue to look for biomarkers, the Alzheimer's Forum has identified more than 1,395 studies working on 695 genes $^{[88]}$ accounting for only up to 0.5 percent of Alzheimer's disease. ${ }^{[89]}$ Genetic studies will never provide the exclusive solution for understanding or curing Alzheimer's disease.

A third source of confusion comes from the fact that clinicians often misdiagnose Alzheimer's disease. There are issues with the diagnostic criteria, made worse by the fact that most older adults experience concurrent multiple morbidities that can mimic or obscure the disease. There is also evidence that some patients acquiesce to the disease label despite being told of the mistaken diagnosis. ${ }^{[90]}$ This in turn results in Alzheimer's disease being over-registered and overdiagnosed, ${ }^{[91]}$ resulting in wasted health care expenditures ${ }^{[92]}$ and undue stress on the family. ${ }^{[93]}$ Despite an awareness of these problems, and steps taken to address them, ${ }^{[94]}$ a rigid adherence to the existing status quo continues to influence the types of research being conducted.

\section{Conclusion}

There is no denying the devastating impact of an illness that destroys the mind, changes behavior, and affects the personhood. The disease affects not just the victim but is affecting the lives of whole families across generations. This emerging pandemic will in turn transform our society. Hopefully this paper will promote a broader approach to studying Alzheimer's disease, allowing for a wider spectrum of scientists to become involved in finding what Alzheimer's is and subsequently finding a cure. We still do not know what causes Alzheimer's disease or indeed what it is. This confusion is not new, and to this day researchers question whether Alzheimer's disease is "an inevitable part of 'normal' aging, or a bona fide neuropathological disease, entirely different from aging?" (p. 47). ${ }^{[95]}$ It is remarkably similar to questions asked a century ago at the start of Alzheimer's disease research. While "Even today, with technology, research history, and a considerable amount of monetary resources, it is still unclear, for example, how to distinguish the normal from the abnormal in old age or how to explain the appearance of Alzheimer[s]-like plaques and tangles in persons without clinical symptoms." (p.1). ${ }^{[96]}$ The work of researchers who first exposed these inconsistencies ${ }^{[97-100]}$ still remain on the periphery of the discussion and now need to be brought to the center.

The conclusion from these critiques is that clinicians are not diagnosing Alzheimer's disease correctly. ${ }^{[101]}$ Whatever the disease is, Alzheimer's disease is not a simple trigger that starts the profusion of plaques and tangles which then interferes with brain functioning. ${ }^{[16]}$ Alzheimer's disease is likely to have multiple events that can initiate the disease and is likely to have both mediating and moderating factors that promote the disease. It also probably affects individuals differently depending on their resilience and capacity to buffer the disease. As such, the way to change course in research is for funding to expand to cover broader issues other than the search for biomarkers. Funding needs to first address the confusion of diagnostic uncertainty. This will entail training for neurologists and physicians on the many different types of dementia and their possible causes, for patient organizations to focus on better individual-based care, and for the public to understand the many contributing factors of dementia, some of which can be prevented. This is a public health approach to the disease. ${ }^{[102]}$ Ignoring these complexities will have radical social and scientific consequences. Consequences that were prophesied in 1911 when Perusini wrote: "of course, as usually happens when anatomo-pathological datum offers easy enticement, there will be more than one person who, on the basis of these findings will make the most useless and fanciful anatomo-psychic guesses, and those who amuse themselves with anatomically localizing the location of conscience, the will and related matters, would find a good playground, in which the tangles, for instance, might offer the most clear-cut explanation for the disorientation observed in the senile demented patient..." (p. 144). ${ }^{[103]}$ Emerging scientific evidence is exposing the role of the environment, brain plasticity and reserve, the contribution of other diseases and how people with biomarkers for Alzheimer's disease seem to escape its expression. In response to this lack of 
theoretical leadership, researchers are ignoring any theoretical underpinnings and applying pragmatic approaches. One such example has shown how lifestyle changes reverses cognitive decline. ${ }^{[104]}$ Other emerging ad hoc therapies support a broader public health theory of Alzheimer's disease and support the role of lifestyle changes in countering the effects of Alzheimer's disease. ${ }^{[105]}$ After a century of confusion, broad-

\section{REFERENCES}

[1] Wong CW, Quaranta V, Glenner GG. Neuritic plaques and cerebrovascular amyloid in Alzheimer disease are antigenically related. Proceedings of the National Academy of Sciences. 1985; 82(24): 8729-32. http://dx.doi.org/10.1073/pnas . 82.24.8729

[2] Hardy JA, Higgins GA. Alzheimer's disease, the amyloid cascade hypothesis. Science. 1992; 286, 184-5. http://dx.doi.org/10. 1126/science. 1566067

[3] Alzheimer A. (1912) On certain peculiar diseases of old age. Translated by Förstl H \& Levy R. (1991) History Psychiatr. 1991; 2: 71-101. PMid: 11622845.

[4] Berrios GE, Freeman H. Alzheimer and the Dementias. London, Royal Society of Medicine. 1991.

[5] Amaducci LA, Rocca WA, Schoenberg BS. Origin of the distinction between Alzheimer's disease and senile dementia How history can clarify nosology. Neurology. 1986; 36(11): 1497-1497. http://dx.doi.org/10.1212/WNL.36.11.1497

[6] Kraepelin E. Senile and Pre-Senile Dementias in Bick KL, \& Amaducci L. (Eds.). (1987). The Early Story of Alzheimer's Disease: Translation of the Historical Papers by Alois Alzheimer, Oskar Fischer, Francesco Bonfiglio, Emil Kraepelin, Gaetano Perusini. Liviana Press. 1910

[7] Maurer K, Yolk S, Gerbaldo H. Auguste D. and Alzheimer's disease. Lancet. 1997; 349: 1546-9.

[8] Aminoff BZ. Prognosis of Short Survival in Patients With Advanced Dementia as Diagnosed by Aminoff Suffering Syndrome. American journal of Alzheimer's disease and other dementias. 2014; 1533317514539543. PMid: 24939003. http://dx.doi.org/10. $1177 / 1533317514539543$

[9] Karran E, Mercken M, De Strooper B. The amyloid cascade hypothesis for Alzheimer's disease: an appraisal for the development of therapeutics. Nature Reviews Drug Discovery. 2011; 10(9): 698-712. PMid: 21852788. http://dx.doi .org/10.1038/nrd3505

[10] Iqbal K, Liu F, Gong CX. Alzheimer disease therapeutics: Focus on the disease and not just plaques and tangles. Biochemical pharmacology. 2014; 88(4): 631-9. PMid: 24418409. http: //dx.doi.org/10.1016/j.bcp. 2014.01.002

[11] Gilman S, Koller M, Black RS, et al. Clinical effects of A $\beta$ immunization (AN1792) in patients with AD in an interrupted trial. Neurology. 2005; 64(9): 1553-62. PMid: 15883316. http://dx.doi.org/10. 1212/01. WNL.0000159740.16984.3C

[12] Boche D, Denham N, Holmes C, et al. Neuropathology after active $\mathrm{A} \beta 42$ immunotherapy: implications for Alzheimer's disease pathogenesis. Acta neuropathologica. 2010; 120(3): 369-84. PMid: 20632020. http://dx.doi.org/10.1007/s00401-010 -0719-5

[13] Holmes C, Boche D, Wilkinson D, et al. Long-term effects of $\mathrm{A} \beta$ 42 immunisation in Alzheimer's disease: follow-up of a randomised, ening our research emphasis-by acknowledging the clinical and neurological confusion and promoting a public health approach — will navigate us out of this Alzheimer's disease research cul de sac and provide viable research guidelines for prevention, management and cure.

\section{CONFlicts OF INTEREST Disclosure}

The authors declare no conflict of interest. placebo-controlled phase I trial. The Lancet. 2008; 372(9634): 21623. http://dx. doi .org/10.1016/S0140-6736 (08) 61075-2

[14] Folch J, Petrov D, Ettcheto M, et al. Current Research Therapeutic Strategies for Alzheimer's Disease Treatment. Neural Plasticity. 2016 PMid: 26881137. http://dx.doi .org/10.1155/2016/850169 3

[15] Raina P, Santaguida P, Ismaila A, et al. Effectiveness of cholinesterase inhibitors and memantine for treating dementia: evidence review for a clinical practice guideline. Annals of internal medicine. 2008; 148(5): 379-97. http://dx.doi.org/10.7326/0003-4819-1 48-5-200803040-00009

[16] Garrett MD, Valle RJ. A Methodological Critique of The National Institute of Aging and Alzheimer's Association Guidelines for Alzheimer's disease, Dementia and Mild Cognitive Impairment. Dementia: The International Journal of Social Research and Practice. 2014; 1471301214525166.

[17] Bertram L, Tanzi RE. Alzheimer's disease: one disorder, too many genes? Hum Mol Genet. 2004; 13(1): R135-41.

[18] Katzman R. The prevalence and malignancy of Alzheimer disease: a major killer. Archives of Neurology. 1976; 33(4): 217. http: //dx.doi.org/10.1001/archneur.1976.00500040001001

[19] Lopera F, Ardilla A, Martínez A, et al. Clinical features of early-onset Alzheimer disease in a large kindred with an E280A presenilin-1 mutation. Jama. 1997; 277(10): 793-9.

[20] Osborn F. "Development of a Eugenic Philosophy". American Sociological Review. 1937; 2(3): 389-97. http://dx.doi.org/10.23 $07 / 2084871$

[21] Eysenck HJ, Arnold W, Meili R. (Eds.). Encyclopedia of Psychology 1972; Vol. 1, A-F; Vol. 2, 6-Phas - Z. New York: Herder and Herder (now available from Continuum Books/Seabury Press).

[22] Eastman P. This Way In: Scientists Set Dementia Research Goals. Neurology Now. 2013; 9(5): 12-3. http://dx.doi.org/10.1097 /01. NNN.0000436393.29242.88

[23] Homer AC, Honavaz M, Lantos PL, et al. Diagnosing dementia: do we get it right? Bmj. 1998; 297(6653): 894-6.

[24] Robinson R. MRI Can Distinguish CJD from Other Rapid Dementias. Neurology Today. 2011;11(9): 1-18. http://dx.doi.org/10.10 97/01.NT.0000398351.37440.4a

[25] Holmes C, Cairns N, Lantos P, et al. Validity of current clinical criteria for Alzheimer's disease, vascular dementia and dementia with Lewy bodies. The British Journal of Psychiatry. 1999; 174(1): 45-50. http://dx.doi.org/10.1192/bjp.174.1.45

[26] Rukovets O. Lewy Body Dementia: Not Uncommon, but Frequently Misdiagnosed. Neurology Today. 2012.

[27] Wetterling T, Kanitz RD, Borgis KJ. Comparison of different diagnostic criteria for vascular dementia (ADDTC, DSM-IV, ICD-10, 
NINDS-AIREN). Stroke. 1996; 27(1): 30-6. http://dx.doi.org /10.1161/01.STR.27.1.30

[28] Guziak CC, Smith JE. Anxiety Misdiagnosed as Dementia? A Complex Case Successfully Treated Using a Multimodal Biofeedback Approach. Biofeedback, 2014; 42(1): 12-5. http://dx.doi.org /10.5298/1081-5937-42.1.08

[29] Prince M, Acosta D, Chiu H, et al. Dementia diagnosis in developing countries: a cross-cultural validation study. The Lancet. 2003; 361(9361): 909-17.

[30] Gaugler JE, Ascher-Svanum H, Roth DL, et al. Characteristics of patients misdiagnosed with alzheimer's disease and their medication use: an analysis of the NACC-UDS database. BMC geriatrics. 2013; 13(1): 137. PMid: 24354549. http://dx.doi.org/10.1186/147 1-2318-13-137

[31] Wagner GS, McClintock SM, Rosenquist PB, et al. Major depressive disorder with psychotic features may lead to misdiagnosis of dementia: a case report and review of the literature. Journal of psychiatric practice. $2011 ; 17(6)$ : 432. PMid: 22108402. http: //dx.doi.org/10.1097/01.pra.0000407968.57475.ab

[32] Erkinjuntti T, Østbye T, Steenhuis R, et al. The effect of different diagnostic criteria on the prevalence of dementia. New England Journal of Medicine. 1997; 337(23): 1667-74. PMid: 9385127. http://dx.doi.org/10.1056/NEJM199712043372306

[33] Pohjasvaara T, Mäntylä R, Ylikoski R, et al. Comparison of different clinical criteria (DSM-III, ADDTC, ICD-10, NINDS-AIREN, DSMIV) for the diagnosis of vascular dementia. Stroke. 2000; 31(12): 2952-7. http://dx.doi.org/10.1161/01.STR.31.12.2952

[34] Morris JC, Blennow K, Froelich L, et al. Harmonized diagnostic criteria for Alzheimer's disease: recommendations. Journal of internal medicine. 2014; 275(3): 204-13. PMid: 24605805. http: //dx.doi.org/10.1111/joim.12199

[35] McKeith IG, Galasko D, Kosaka K, et al. Consensus guidelines for the clinical and pathologic diagnosis of dementia with Lewy bodies (DLB) Report of the consortium on DLB international workshop. Neurology. 1996; 47(5): 1113-24. http://dx.doi.org/10.1212 /WNL. 47.5 .1113

[36] Vahl CF. Lewy body and parkinsonian dementia: common, but often misdiagnosed conditions: Hydrocephalus should not be forgotten. Deutsches Arzteblatt International. 2011; 108(8): 131-author.

[37] Mollenhauer B, Förstl H, Deuschl G. Lewy body and parkinsonian dementia: common, but often misdiagnosed conditions. Deutsches Ärzteblatt International. 2010; 107(39): 684.

[38] Kalaria RN, Ballard C. Overlap between pathology of Alzheimer disease and vascular dementia. Alzheimer Disease \& Associated Disorders. 1999; 13, S115-23. http://dx.doi.org/10.1097/0 0002093-199912003-00017

[39] Roman G. Vascular dementia may be the most common form of dementia in the elderly. Journal of the Neurological Sciences. 2002; 203: 7-10. PMid: 12417349.

[40] Haslam C, Morton TA, Haslam SA, et al. "When the age is in, the wit is out": Age-related self-categorization and deficit expectations reduce performance on clinical tests used in dementia assessment. Psychology and aging. 2012; 27(3): 778. PMid: 22468850 http://dx.doi.org/10.1037/a0027754

[41] Hess TM, Auman C, Colcombe SJ, et al. The impact of stereotype threat on age differences in memory performance. The Journals of Gerontology Series B: Psychological Sciences and Social Sciences. 2003; 58(1): 3-11.

[42] Hess TM, Hinson JT, Statham JA. Explicit and implicit stereotype activation effects on memory: Do age and awareness moderate the impact of priming?. Psychology and aging. 2004; 19(3):
495. PMid: 15382999. http://dx.doi.org/10.1037/0882-797 4.19.3.495

[43] Merckelbach H, Jelicic M, Jonker C. Planting a misdiagnosis of Alzheimer's disease in a person's mind. Acta neuropsychiatrica. 2012; 24(1): 60-2. PMid: 25288461. http://dx.doi.org/10.1111/j $.1601-5215.2011 .00586 . \mathrm{x}$

[44] Jack CR. Jr, Knopman DS, Jagust WJ, et al. Hypothetical model of dynamic biomarkers of the Alzheimer's pathological cascade. Lancet Neurology. 2010; 9: 119-28. http://dx.doi.org/10.1016/S14 74-4422 (09) 70299-6

[45] Sperling RA, Aisen PS, Beckett LA, et al. Towards defining the preclinical stages of Alzheimer's disease: Recommendations from the National Institute on Aging-Alzheimer's Association workgroups on diagnostic guidelines for Alzheimer's disease. Alzheimers Dement. 2011; 7: 280-92.

[46] Albert MS, DeKosky ST, Dickson D, et al. The diagnosis of mild cognitive impairment due to Alzheimer's disease: Recommendations from the National Institute on Aging-Alzheimer's Association workgroups on diagnostic guidelines for Alzheimer's disease. Alzheimer's \& Dementia. 2011; 7(3): 270-9. PMid: 21514249. http://dx.doi.org/10.1016/j.jalz.2011.03.008

[47] McKhann GM, Knopman DS, Chertkow H, et al. The diagnosis of dementia due to Alzheimer's disease: Recommendations from the National Institute on Aging-Alzheimer's Association workgroups on diagnostic guidelines for Alzheimer's disease. Alzheimer's \& Dementia, 2011; 7(3): 263-9. PMid: 21514250. http://dx.doi.org $/ 10.1016 / \mathrm{j} \cdot \mathrm{jalz} .2011 .03 .005$

[48] Sperling RA, Aisen PS, Beckett LA, et al. Towards defining the preclinical stages of Alzheimer's disease: Recommendations from the National Institute on Aging-Alzheimer's Association workgroups on diagnostic guidelines for Alzheimer's disease. Alzheimers Dement. 2011; 7: 280-92. PMid: 21514248. http://dx.doi.org/10.10 $16 / \mathrm{j} \cdot \mathrm{jalz} .2011 .03 .003$

[49] Mattsson N, Brax D, Zetterberg H. To know or not to know: ethical issues related to early diagnosis of Alzheimer's disease. International journal of Alzheimer's disease. 2010. PMid: 20798843. http://dx.doi.org/10.4061/2010/841941

[50] Metlife. What America Thinks. MetLife Foundation Alzheimer's Survey, Conducted by Harris Interactive. Accessed 8/16/2013: Available from: https://www.metlife.com/assets/cao/foundation/ alzheimers-2011.pdf

[51] Weinberger DR, Goldberg TE. RDoCs redux. World Psychiatry. 2014; 13(1): 36-8. PMid: 24497241. http://dx.doi.org/10.1002/w ps. 20096

[52] Nagy ZS, Esiri MM, Jobst KA, et al. Relative roles of plaques and tangles in the dementia of Alzheimer's disease: correlations using three sets of neuropathological criteria. Dementia and Geriatric Cognitive Disorders. 1995; 6(1): 21-31. http://dx.doi.org/10.11 59/000106918

[53] Arriagada PV, Growdon JH, Hedley-Whyte ET, et al. Neurofibrillary tangles but not senile plaques parallel duration and severity of Alzheimer's disease. Neurology. 1992; 42(3): 631-631. http: //dx.doi.org/10.1212/WNL.42.3.631

[54] Andrade-Moraes CH, Oliveira-Pinto AV, Castro-Fonseca E, et al. Cell number changes in Alzheimer's disease relate to dementia, not to plaques and tangles. Brain. 2013; 136(12): 3738-52. PMid: 24136825. http://dx.doi.org/10.1093/brain/awt273

[55] Frisoni GB, Testa C, Zorzan A, et al. Detection of grey matter loss in mild Alzheimer's disease with voxel based morphometry. Journal of Neurology, Neurosurgery \& Psychiatry. 2002; 73(6): 657-64. http://dx.doi.org/10.1136/jnnp.73.6.657 
[56] Englund E. Neuropathology of white matter changes in Alzheimer's disease and vascular dementia. Dementia and geriatric cognitive disorders. 1998; 9(Suppl. 1): 6-12. http://dx.doi.org/10.1159/0 00051183

[57] Fields RD, Stevens-Graham B. New insights into neuron-glia communication. Science. 2002; 298(5593): 556-62.

[58] Chalmers K, Wilcock G, Love S. Contributors to white matter damage in the frontal lobe in Alzheimer's disease. Neuropathology and applied neurobiology. 2005; 31(6): 623-31. PMid: 16281911. http://dx.doi.org/10.1111/j.1365-2990.2005.00678.x

[59] Gould E, Tanapat P, Hastings NB. Neurogenesis in adulthood: a possible role in learning. Trends in cognitive sciences. 1999; 3(5): 186-92. http://dx.doi.org/10.1016/S1364-6613(99)01310-8

[60] Woollett K, Maguire EA. Acquiring "the Knowledge" of London's layout drives structural brain changes. Current biology. 2011; 21(24): 2109-14. PMid: 22169537. http://dx.doi.org/10.1016/j.c ub. 2011.11 .018

[61] Scholz J, Klein MC, Behrens TE, et al. Training induces changes in white-matter architecture. Nature neuroscience. 2009; 12(11): 13701. PMid: 19820707. http://dx.doi.org/10.1038/nn. 2412

[62] Schlegel AA, Rudelson JJ, Peter UT. White matter structure changes as adults learn a second language. Journal of cognitive neuroscience. 2012; 24(8): 1664-70. PMid: 22571459. http://dx.doi.org/10. $1162 /$ jocn_a_00240

[63] Alzheimer A. (1907) A Characteristic Disease of the Cerbral Cortex in Bick KL, \& Amaducci L. (Eds.). (1987). The Early Story of Alzheimer's Disease: Translation of the Historical Papers by Alois Alzheimer, Oskar Fischer, Francesco Bonfiglio, Emil Kraepelin, Gaetano Perusini. Liviana Press.

[64] O'Brien JT. Clinical Significance of White Matter Changes. The American Journal of Geriatric Psychiatry. 2014; 22(2): 133-7. PMid: 24041523. http://dx.doi.org/10.1016/j.jagp. 2013 .07 .006

[65] Taubert M, Draganski B, Anwander A, et al. Dynamic properties of human brain structure: learning-related changes in cortical areas and associated fiber connections. The Journal of Neuroscience. 2010; 30(35): 11670-7. PMid: 20810887. http://dx.doi.org/10.15 23/JNEUROSCI . 2567-10.2010

[66] Liepert J, Graef S, Uhde I, et al. Training-induced changes of motor cortex representations in stroke patients. Acta Neurologica Scandinavica. 2000; 101(5): 321-6. http://dx.doi.org/10.1034/j.1 600-0404.2000.90337a.x

[67] Wan CY, Schlaug G. Music making as a tool for promoting brain plasticity across the life span. The Neuroscientist. 2010; 16(5), 566-77. PMid: 20889966. http://dx.doi.org/10.1177/10738584103 77805

[68] Schmithorst VJ, Wilke M. Differences in white matter architecture between musicians and non-musicians: a diffusion tensor imaging study. Neuroscience letters. 2002; 321(1): 57-60. http: //dx.doi.org/10.1016/S0304-3940(02)00054-X

[69] Taubert M, Lohmann G, Margulies DS, et al. Long-term effects of motor training on resting-state networks and underlying brain structure. Neuroimage. 2011; 57(4): 1492-8. PMid: 21672633. http://dx.doi.org/10.1016/j.neuroimage.2011.05.078

[70] Bezzola L, Mérillat S, Gaser C, et al. Training-induced neural plasticity in golf novices. The Journal of Neuroscience. 2011; 31(35): 12444-8. PMid: 21880905. http://dx.doi.org/10.1523/JNE UROSCI . 1996-11.2011

[71] Lee B, Park JY, Jung WH. White matter neuroplastic changes in longterm trained players of the game of "Baduk"(GO): a voxel-based diffusion-tensor imaging study. Neuroimage. 2010; 52(1): 9-19.
[72] Tang YY, Lu Q, Geng X, et al. Short-term meditation induces white matter changes in the anterior cingulate. Proceedings of the National Academy of Sciences. 2010; 107(35): 15649-52. PMid: 20713717. http://dx.doi.org/10.1073/pnas. 1011043107

[73] Moreno S, Bialystok E, Barac R, et al. Short-term music training enhances verbal intelligence and executive function. Psychological science. 2011; 22(11): 1425-33. PMid: 21969312. http: //dx.doi.org/10.1177/0956797611416999

[74] Mackey AP, Whitaker KJ, Bunge SA. Experience-dependent plasticity in white matter microstructure: reasoning training alters structural connectivity. Frontiers in Neuroanatomy. 2012. PMid: 22936899 http://dx.doi.org/10.3389/fnana.2012.00032

[75] Snowdon DA. Healthy aging and dementia: findings from the Nun Study. Annals of Internal Medicine. 2003; 139(5,2): 450-4. http://dx.doi.org/10.7326/0003-4819-139-5_Par t_2-200309021-00014

[76] Ballesteros S, Nilsson LG, Lemaire P. Ageing, cognition, and neuroscience: An introduction. European Journal of Cognitive Psychology. 2009; 21(2-3): 161-75. http://dx.doi.org/10.1080/0954144 0802598339

[77] Brumback-Peltz C, Balasubramanian AB, Corrada MM, et al. Diagnosing dementia in the oldest-old. Maturitas. 2011; 70(2): 164-8.

[78] Savva GM, Wharton SB, Ince PG, et al. Age, neuropathology, and dementia. New England Journal of Medicine. 2009; 360(22): 2302-9. PMid: 19474427. http://dx.doi.org/10.1056/NEJMoa08061 42

[79] Giannakopoulos P, Gold G, Kövari E, et al. Assessing the cognitive impact of Alzheimer disease pathology and vascular burden in the aging brain: the Geneva experience. Acta neuropathologica. 2007; 113(1): 1-12. PMid: 17036244. http://dx.doi.org/10.1007/s 00401-006-0144-y

[80] Crystal H, Dickson D, Fuld P, et al. Clinico-pathologic studies in dementia Nondemented subjects with pathologically confirmed Alzheimer's disease. Neurology. 1998; 38(11): 1682-1682. http: //dx.doi.org/10.1212/WNL.38.11.1682

[81] Polvikoski T, Sulkava R, Myllykangas L, et al. Prevalence of Alzheimer's disease in very elderly people A prospective neuropathological study. Neurology. 2011; 56(12), 1690-6. http://dx.doi.o $\mathrm{rg} / 10.1212 / \mathrm{WNL} .56 .12 .1690$

[82] Ascher-Svanum H, Gaugler J, Roth D, et al. Characteristics of people misdiagnosed with Alzheimer's disease and their medication use: An analysis of the National Alzheimer's Coordinating Center Uniform Data Set database. Alzheimer's \& Dementia: The Journal of the Alzheimer's Association. 2013; 9(4): 734-734.

[83] Qiu C, De Ronchi D, Fratiglioni L. The epidemiology of the dementias: an update. Current opinion in psychiatry. 2007; 20(4): 380-5. PMid: 17551353. http://dx.doi.org/10.1097/YCo.0b013e3 $2816 \mathrm{ebc} 7 \mathrm{~b}$

[84] Nielsen TR, Andersen BB, Kastrup M, et al. Quality of dementia diagnostic evaluation for ethnic minority patients: a nationwide study. Dementia and geriatric cognitive disorders. 2011; 31(5): 388-96. PMid: 21720163. http://dx.doi.org/10.1159/000327362

[85] Black S, Simpson GM. A Call to Action: Dementia Screening of Alzheimer's Disease in Older African Americans. In The Collective Spirit of Aging Across Cultures (pp. 229-238). Springer Netherlands. 2014. http://dx. doi.org/10.1007/978-94-017 $-8594-5 \_13$

[86] Sayegh P, Knight BG. Assessment and Diagnosis of Dementia in Hispanic and Non-Hispanic White Outpatients. The Gerontologist. 2013; 53(5): 760-9. PMid: 23348889. http://dx.doi.org/10. 1093/geront/gns190 
[87] Gatz M, Pedersen NL, Berg S, et al. Heritability for Alzheimer's disease: the study of dementia in Swedish twins. The Journals of Gerontology Series A: Biological Sciences and Medical Sciences. 1997; 52(2): 117-25.

[88] Alzheimer's forum (accessed 9/22/2014; Available from: http: //www.alzforum.org/alzgene)

[89] Alzheimer's Disease and Frontotemporal Dementia Mutation Database (2014) accessed 12/12/2014. Available from: http:// www.molgen.vib-ua.be/ADMutations

[90] McDaniel LD, Lukovits T, McDaniel KD. Alzheimer's Disease: The Problem of Incorrect Clinical Diagnosis. Journal of Geriatric Psychiatry and Neurology. 1993; 6(4): 230-4. PMid: 8251052. http://dx.doi.org/10.1177/089198879300600409

[91] Salem LC, Andersen BB, Nielsen TR, et al. Overdiagnosis of Dementia in Young Patients-A Nationwide Register-Based Study. Dementia and geriatric cognitive disorders. 2012; 34(5-6): 292-9. PMid: 23208125. http://dx.doi.org/10.1159/000345485

[92] Kirson N, Hunter C, Desai U, et al. Excess costs associated with misdiagnosis of Alzheimer's disease among US Medicare beneficiaries with vascular dementia or Parkinson's disease. Alzheimer's \& Dementia: The Journal of the Alzheimer's Association. 2013; 9(4): 845-6.

[93] Christakis NA. Death Foretold: Prophecy and Prognosis in Medical Care. Chicago: University of Chicago Press. Chicago, USA. 1999.

[94] Chui HC, Victoroff JI, Margolin D, et al. Criteria for the diagnosis of ischemic vascular dementia proposed by the State of California Alzheimer's Disease Diagnostic and Treatment Centers. Neurology. 1992; 42(3): 473-473. http: //dx . doi .org/10.1212/WNL . 42 . 3. 473

[95] Lock M. Dementia entanglements in a postgenomic era. Science, Technology \& Human Values. 2011; 36(5): 685-703. http://dx.d oi.org/10.1177/0162243910388022

[96] Holstein M. Alzheimer's disease and senile dementia, 1885-1920: An interpretive history of disease negotiation. Journal of Aging Stud- ies. 1997; 11(1): 1-13. http://dx.doi.org/10.1016/S0890-4 065 (97) $90008-6$

[97] Mitchell HW. Address Before the Fiftieth Annual Meeting of the American Medico-Psychological Association. Journal of Nervous and Mental Disorders. 1894; 21: 413-7. http://dx.doi.org/10. 1097/00005053-189407000-00001

[98] Southard EE, Mitchell HW. Clinical and Anatomical Analysis of 23 Cases of Insanity Arising in the 6th and 7th Decades with Especial Relation to the Incident of Arteriosclerosis and Senile Atrophy and to the Distribution of Cortical Plaques. American Journal of Insanity. 1908; 65: 293-336.

[99] Southard EE. Anatomical Findings in Senile Dementia: A Diagnostic Study Bearing Especially on the Group of Cerebral Atrophies. American Journal of Insanity. 1910; 66: 673-707.

[100] Fuller S, Klopp HI. Further observations on Alzheimer's disease. 1912.

[101] George DR, Qualls SH, Camp CJ, et al. Renovating Alzheimer's: "Constructive" reflections on the new clinical and research diagnostic guidelines. The Gerontologist, gns096. 2012.

[102] Garrett MD, Valle R. A New Public Health Paradigm for Alzheimer's Disease Research. SOJ Neurol. 2015; 2(1): 1-9.

[103] Perusini G. Histology and Clinical Findings of Some Psychiatric Disease of older People in Bick KL, \& Amaducci L. (Eds.). (1987). The Early Story of Alzheimer's Disease: Translation of the Historical Papers by Alois Alzheimer, Oskar Fischer, Francesco Bonfiglio, Emil Kraepelin, Gaetano Perusini. Liviana Press. 1910.

[104] Bredesen DE. Reversal of cognitive decline: A novel therapeutic program. Aging (Albany NY). 2014; 6(9): 707.

[105] Nelson L, Tabet N. Slowing the progression of Alzheimer's disease; what works?. Ageing research reviews. 2015; 23: 193-209. PMid: 26219494. http://dx.doi.org/10.1016/j.arr. 2015. 07.002 